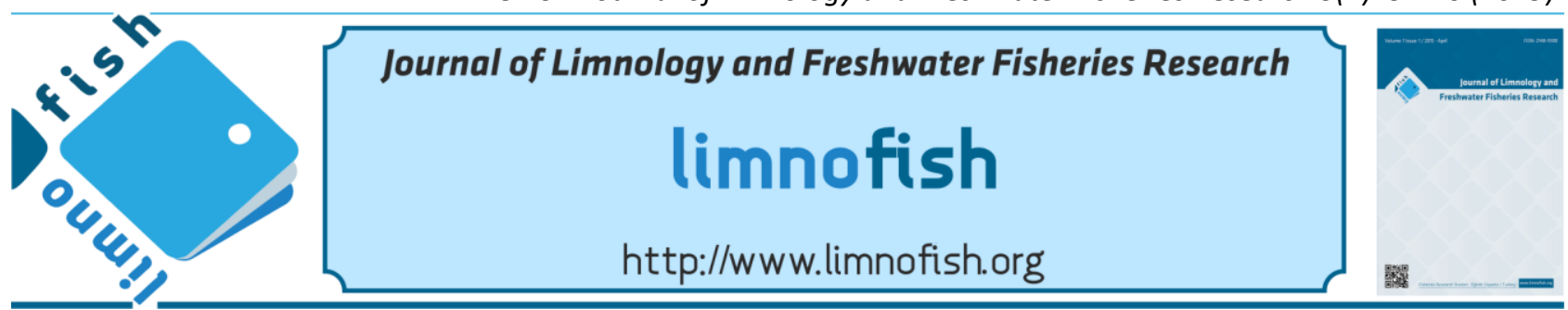

\title{
Dietary Protein Requirements of Zebrafish (Dania rerio)
}

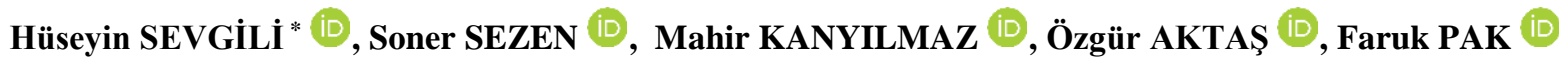

Mediterranean Fisheries Research Production and Training Institute, Kepez Unit, 07192, Döşemealt1, Antalya, Turkey

\section{A B S TRACT}

Zebrafish (Danio rerio) with an initial weight of $88.61 \pm 0.82 \mathrm{mg}$ were fed eight isoenergetic diets containing dietary protein levels ranging from 20 to $55 \%$ by 5 $\%$ increments. Each diet was feed in triplicate of fish for 6 weeks. Specific growth rates $(S G R)$ at week 2 and 4 were quadratically affected by the treatments but this trend disappeared at the end of the experiment. Dietary protein levels linearly reduced the values of daily feed intake, feed conversion ratio and protein efficiency rate. The whole body dry matter, ash and lipid concentrations linearly decreased with dietary protein levels whereas whole body protein was quadratically affected. The second order polynomial and two break point linear models $(T B P L M)$ were used to estimate dietary protein requirements. The later model generated lower residual sum of squares when $S G R_{W e e k}$ and $S G R_{\text {Final }}$ values were used as a response. Minimum dietary protein requirements for $S G R_{W e e k} 4$ and $S G R_{\text {Final }}$ were estimated by the TBPLM as 27.69 and $28.93 \%$ respectively. Briefly, results of the study suggest a minimum dietary protein requirement of zebrafish is about $29 \%$ for maximum growth rate.

Keywords: Zebrafish, dietary protein, growth, feeding

\section{ARTICLE INFO}

\section{RESEARCH ARTICLE}

Received : 04.07.2018

Revised : :22.10.2018

Accepted : 30.10 .2018

Published : :25.04.2019

DOI:10.17216/LimnoFish.440537

\section{* CORRESPONDING AUTHOR}

husevgili@yahoo.com

Phone : +90242 2510585

\section{Zebra Balığının (Dania rerio) Diyetsel Protein Gereksinimi}

Öz: Ortalama başlangıç ağırlığı 88,61 $\pm 0,82 \mathrm{mg}$ olan zebra balıkları (Danio rerio) protein düzeyi \% 20-55 arasında değişen sekiz adet izoenerjitik yemle beslenmiştir. Her bir deneme yemi üç tekrarlı olarak 6 hafta boyunca balıklara verilmiştir. Spesifik büyüme oranı $(S G R)$ 2. ve 4. haftalarda kuadratik olarak etkilenirken, bu eğilim deneme sonunda kaybolmuştur. Protein düzeyleri arttıkça yem tüketimi, yemden yararlanma oranı ve protein etkinlik oranı doğrusal olarak düşmüştür. Tüm vücut kuru madde, kül ve lipit konsantrasyonları diyetsel protein düzeyinin artış1 ile doğrusal olarak düşmüş, vücut protein düzeyi ise kuadratik olarak etkilenmiştir. Diyetsel protein gereksinimlerini tahmin etmek için, ikinci derece regresyon ve iki kırıklı linear model (IKLM) kullanılmıştır. 4. hafta ve deneme sonu $S G R$ değerleri kullanıldığında IKLM daha düşük kalıntı kareler toplamı vermiştir. 4. hafta ve final $S G R$ oranlarına göre, IKLM minimum protein gereksinimlerini sırasıyla, \% 27,69 ve \% 28,93 olarak tahmin etmiştir. Kısaca, çalışma bulguları zebra balıklarının maksimum büyüme için minimum protein gereksinimlerinin yaklaşı \% 29 olduğunu göstermektedir.

Anahtar kelimeler: Zebra balığı, diyetsel protein, büyüme, yemleme

How to Cite

Sevgili H, Sezen S, Kanyılmaz M, Aktaş Ö, Pak F. 2019. Dietary Protein Requirements of Zebrafish (Dania rerio). LimnoFish. 5(1): 34-40. doi: 10.17216/LimnoFish.440537

\section{Introduction}

Zebrafish is used in a wide range of scientific disciplines as a model animal. Basic culture requirements particularly nutritional needs of zebrafish however are still incomplete (Lawrence 2007; Ulloa et al. 2014). Existing literature about zebrafish nutrition has dealt with some topics including the evaluation several diet types and protein sources (Artemia, paste liver, flake, commercial trout and experimental diets) in terms of reproductive and growth performance (Markovich et al. 2007; Siccardi III et al. 2009; Smith Jr et al. 2013), biotin requirements (Yossa et al. 2014) and effects of dietary carbohydrate levels on growth and nutrient utilization performance and hepatic transcriptome by sexes (Robison et al. 2008), although there are some others.

Dietary protein level in fish is considered as one of most important criterions since it is most the expensive nutrient and affects a number of functions from molecular level to growth related traits (Lawrence 2007; NRC 2011; Ulloa et al. 2011; Ulloa 
et al. 2014). Despite its fundamental importance in nutritional physiology, dietary protein requirement of juvenile zebrafish has been studied recently by Fernandes et al. (2016), who estimated the minimum dietary requirements between 37.6 and $44.8 \%$ for maximum weight gain and protein retention using a four-parameter saturation kinetics model $(S K M)$ and broken line model (BLM). O'Brine et al. (2015) also studied protein and lipid requirements of older zebrafish ( $c a .4$ months) and reported using ANOVA that diet with $32 \%$ dietary and $8 \%$ lipid can be sufficient for growth. Growth rate of zebrafish can vary greatly by laboratories, populations and batches (Eaton and Farley 1974), plus the estimations dietary requirements of fish are subjected to huge variations due to the selected statistical model and response variables (Hernandez-Llamas 2009; NRC 2011). Therefore, a six-week feeding trial with juvenile zebrafish from 42 to 84 days post hatching was planned to estimate dietary protein requirements.

\section{Materials and Methods}

\section{Fish and rearing system}

The experiment was carried out at the Kepez Unit of Mediterranean Fisheries Research Production and Training Institute, Antalya, Turkey. A total of 720, 35day post hatching zebrafish (pink type) were randomly allocated in groups of 30 across $24,10 \mathrm{~L}$ tanks. Fish were acclimated for a week and fed a commercial rainbow trout diet with $60 \%$ protein and $10 \%$ lipid and 150-300 $\mu \mathrm{m}$ particle diameter (Bioaqua, Çamlı Yem, İzmir, Turkey). The average individual weight per tank was $88.61 \pm 0.82 \mathrm{mg}$ and the age was 6 weeks.

The experimental tanks were connected to a recirculation system. Daily water renewal rate of the system was $30 \%$. Each tank was given $100 \mathrm{~mL} / \mathrm{min}$ of water and provided with aeration using one air stone. Average water temperature, oxygen, $\mathrm{pH}, \mathrm{NH}_{4}$ $\mathrm{N}$ and $\mathrm{NO}_{2}-\mathrm{N}$ concentrations in the system over the experiment were checked twice a week and were $24.87 \pm 0.49^{\circ} \mathrm{C}, 7.65 \pm 0.06 \mathrm{mg} / \mathrm{L}, 8.52 \pm 0.06,<0.02$ $\mathrm{mg} / \mathrm{L}$ and $0.013 \pm 0.003 \mathrm{mg} / \mathrm{L}$, respectively. A natural photoperiod was applied as 13-14 h L: 11-10 h D.

Fish were biweekly weighed in bulk after an anesthetization with ethylene glycol monophenyl ether $(0.3 \mathrm{~mL} / \mathrm{L})$. Feed was withheld on the weighing days. Feed particle diameters were 300-500, 500-800 and $800-1000 \mu \mathrm{m}$ during $0-2,2-4$ and 4-6 weeks of the experiment. Fish were fed ad libitum by hand twice a day at 09:00 and 16:00 h. Each feed was tried in triplicated tanks and was carefully administered until the feeding activity ceased. At the start of the experiment, a composite sample of five fish per tank were taken for initial body composition whereas at the end of the experiment, all fish per tank were sacrificed by an overdose of ethylene glycol monophenyl ether $(1.2 \mathrm{~mL} / \mathrm{L})$ for final proximate analysis.

\section{Experimental diets}

Diets were formulated based on dry matter basis using the linear method in Winfeed 2.8 (Winfeed Ltd., Cambridge, UK). Eight isoenergetic diets (18 $\mathrm{MJ} / \mathrm{kg}$ gross energy $(G E)$ ) were formulated to provide crude protein $(C P)$ levels from 20 to $55 \%$ by $5 \%$ increments (Table 1 ). The dietary protein level was increased by adjusting the fraction of the fish meal in the diet. Fish meal was used were used as primary protein source whereas a 1:1 mixture of soybean meal and corn gluten meal was used as secondary protein source. Wheat starch and sunflower oil served as carbohydrate and lipid sources, respectively.

All the dietary ingredients were ground with a hammer mill (Kocamaz Machine, Model KT-20C, İzmir, Turkey), weighed at predetermined levels, thoroughly mixed and then extruded into $2 \mathrm{~mm}$ using a pasta machine (model P3, La Monferrina, Italy). The resulting material was air dried at a room.

\section{Calculation and chemical analysis}

Daily feed intake $(D F I \mathrm{~g} / \mathrm{kg} M B W /$ day $)=($ dry matter intake / $\left.M B W^{0.8}\right) /$ day

Metabolic body weight $(M B W)=($ Geometric mean of initial weight $(I W)$ and final weight $(F W))^{0.8}$

Specific growth rate $(S G R)=100 \times[(\ln F W-\ln$ $I W) /$ day

Daily feed intake $\left(\mathrm{mg} / \mathrm{kg} M B W^{0.8} / \mathrm{day}^{-1}\right)=($ dry feed intake / $M B W^{0.8}$ ) / days

Feed conversion ratio $(F C R)=$ dry matter intake $/$ weight gain

Protein efficiency ratio $(P E R)=$ weight gain $/$ protein fed

Daily nutrient intake $\left(\mathrm{g} / \mathrm{kg} M B W^{0.8} / \mathrm{day}^{-1}\right)=[($ protein, energy intake / $\left.M B W^{0.8}\right) /$ days.

Daily nutrient gain $\left(\mathrm{g} / \mathrm{kg} M B W^{0} \cdot 8 /\right.$ day $)=[($ final body weight $\times$ final body nutrient) - (initial body weight $\times$ initial body nutrient)] $/ M B W^{0.8} /$ days.

Nutrient retention $(\%)=100 \times($ daily nutrient gain / daily nutrient intake).

Fish samples were stored at $-20^{\circ} \mathrm{C}$ until analysis. Prior to analysis, they were chopped into very tiny pieces using knife. Proximate analysis, except crude lipid, of experimental diets and fish were performed according to the methods of AOAC (1990): dry matter at $104{ }^{\circ} \mathrm{C}$ till constant weight, ash content by incineration in a muffle furnace at $600{ }^{\circ} \mathrm{C}$ for $2 \mathrm{~h}$; CP $(\mathrm{N} \times 6.25)$ by the Kjeldhal method after acid digestion. 
Lipid was determined with ether-extraction using an automatic extraction system (ANKOMXT15 Extractor, ANKOM Technology, Macedon, USA).

\section{Statistical analysis}

Polynomial contrasts were used to detect linear and quadratic effects of dietary protein levels on the observed response variables. Significant treatment effects were considered at $\mathrm{P} \leq 0.10$. Statistical analyses were conducted in JMP v.8.0 (SAS Institute Inc. 2008). To estimate dietary protein requirements for average $S G R_{W e e k 4}$ and $S G R_{\text {Final }}$, two models were tested using GRAPHPAD PRISM 5 for Windows (GraphPad Software, San Diego, CA, USA): second order polynomial regression and two-break points non-linear model (TBPLM). The latter is a combination of conventional broken line model (Hernandez-Llamas 2009) with a negative linear regression at the right side of the response curve. The optimum dietary protein levels were defined based on the model fitting best in terms of the residual sum of squares (Hernandez-Llamas 2009).

The equations of second order polynomial regression (1) and TBPLM (2, 3 and 4) are given below.

$$
y=i_{1}+b_{1} x+b_{2} x^{2}
$$

where $i_{1}$ is intercept, b1 and b2 is are the regression coefficients (Shearer 2000).

$$
\begin{array}{ll}
y=i_{1}+b_{1} x & \text { if } x<x_{\mathrm{bp}}, \\
y=y_{\text {max }}+b_{2} x & \text { if } x \geq x_{\mathrm{bp}}, \\
y=i_{2}+b_{3} x & \text { if } x>x_{\mathrm{bp}}
\end{array}
$$

where $i_{1}$ and $b_{1}$ are parameters describing the positive linear relation, $y_{\max }$ is the maximum response and $i_{2}$ and $b_{3}$ are parameters of negative linear

\begin{tabular}{|c|c|c|c|c|c|c|c|c|}
\hline Ingredients & $20 \mathrm{P}$ & $25 \mathrm{P}$ & $30 \mathrm{P}$ & $35 \mathrm{P}$ & $40 \mathrm{P}$ & $45 \mathrm{P}$ & $50 \mathrm{P}$ & $55 \mathrm{P}$ \\
\hline Fish meal & 19.87 & 26.49 & 30.90 & 37.51 & 41.92 & 48.54 & 52.95 & 59.56 \\
\hline Soybean meal & 2.14 & 3.06 & 3.67 & 4.59 & 5.20 & 6.12 & 6.73 & 7.65 \\
\hline Corn gluten meal & 2.14 & 3.06 & 3.67 & 4.59 & 5.20 & 6.12 & 6.73 & 7.65 \\
\hline Wheat starch (Cooked) & 64.15 & 54.83 & 48.61 & 39.28 & 33.07 & 23.74 & 17.53 & 8.20 \\
\hline Sunflower oil & 8.21 & 7.53 & 7.08 & 6.40 & 5.94 & 5.26 & 4.81 & 4.13 \\
\hline $\mathrm{MCP}^{1}$ & 2.24 & 2.07 & 1.96 & 1.80 & 1.68 & 1.52 & 1.41 & 1.24 \\
\hline Mineral mixture ${ }^{2}$ & 0.1 & 0.1 & 0.1 & 0.1 & 0.1 & 0.1 & 0.1 & 0.1 \\
\hline Vitamin mixture $^{3}$ & 0.5 & 0.5 & 0.5 & 0.5 & 0.5 & 0.5 & 0.5 & 0.5 \\
\hline Choline chloride & 0.15 & 0.15 & 0.15 & 0.15 & 0.15 & 0.15 & 0.15 & 0.15 \\
\hline$C M C^{4}$ & 0.5 & 0.5 & 0.5 & 0.5 & 0.5 & 0.5 & 0.5 & 0.5 \\
\hline Alpha cellulose $e^{5}$ & 0.00 & 1.72 & 2.87 & 4.59 & 5.73 & 7.45 & 8.60 & 10.32 \\
\hline \multicolumn{9}{|l|}{ Nutrient levels (\% dry matter) } \\
\hline Dry matter & 91.41 & 91.74 & 91.64 & 91.89 & 92.31 & 92.24 & 92.66 & 92.49 \\
\hline Crude ash & 5.75 & 6.73 & 6.94 & 7.63 & 8.21 & 8.98 & 9.71 & 10.51 \\
\hline Crude lipid & 10.26 & 10.02 & 10.32 & 10.94 & 10.62 & 9.97 & 10.28 & 10.34 \\
\hline Crude protein & 20.38 & 26.22 & 28.93 & 34.94 & 39.56 & 44.20 & 49.72 & 56.88 \\
\hline Gross energy $(M J / \mathrm{kg})$ & 19.82 & 19.69 & 19.70 & 19.81 & 19.74 & 19.47 & 19.58 & 19.62 \\
\hline Protein energy ratio $(\mathrm{g} / M J)$ & 10.28 & 13.32 & 14.69 & 17.64 & 20.04 & 22.70 & 25.39 & 28.99 \\
\hline
\end{tabular}
relation. To assume a constant response, the slope at the plateau $\left(b_{2}\right)$ was set at zero.

Table 1. Formulation and nutrient composition of experimental diets ( $\%$ dry matter)

\section{Results}

All experimental groups more than tripled their initial weights during the 6-week experiment (Table 2). There was a weak quadratic effect of dietary protein levels on $4^{\text {th }}$ week weight (quadratic, $\mathrm{P}=0.104$ ) but it disappeared at the final. $S G R$ values at week 2 and 4 were quadratically affected by the treatments (quadratic, $\mathrm{P}=0.025$ and $\mathrm{P}=0.060$ respectively), which also vanished at the end of the experiment (linear, $\mathrm{P}=0.666$ and quadratic, $\mathrm{P}=0.213$ ) (Table 2). Dietary protein levels had a strong linear effect on daily feed intake, $F C R$ and $P E R$ (linear, $\mathrm{P}=<0.001$ ).

The second order polynomial model generated 0.0148 and 0.0293 of residual sum of squares for $S G R_{\text {Week } 4}$ and $S G R_{\text {Final }}$ respectively, whereas the TBPLM yielded lower levels with 0.0128 and 0.0248 . Minimum dietary protein requirements for $S G R_{\text {Week } 4}$ and $S G R_{\text {Final }}$ were estimated by the TBPLM as 27.69 and $28.93 \%$ respectively (Figure 1 ). 
Table 2. Growth, and nutrient utilization performance of zebrafish fed varying dietary protein levels

\begin{tabular}{|c|c|c|c|c|c|c|c|c|c|c|}
\hline Diets & $\begin{array}{c}I W \\
\text { (mg/ fish) }\end{array}$ & $\begin{array}{c}W \text { at } 2^{\text {nd }} \\
\text { week } \\
\text { (mg/fish) }\end{array}$ & $\begin{array}{c}W \text { at } 4 \text { th } \\
\text { week } \\
\text { (mg/ } \\
\text { fish) }\end{array}$ & $\begin{array}{l}W \text { at final } \\
\text { (mg/fish) }\end{array}$ & $\begin{array}{c}S G R \text { at } \\
2^{\text {nd }} \text { week } \\
(\% / \text { day })\end{array}$ & $\begin{array}{l}S G R \text { at } 4^{\text {th }} \\
\text { week } \\
\text { (\%/day) }\end{array}$ & $\begin{array}{c}S G R \text { at } \\
\text { final } \\
(\% / \text { day })\end{array}$ & $\begin{array}{c}\text { Daily feed } \\
\text { intake }\left(\mathrm{g} / \mathrm{kg}^{-}\right. \\
\left.M B W^{0.8} / \mathrm{day}\right)\end{array}$ & $F C R$ & PER \\
\hline $20 \mathrm{P}$ & 86.81 & 117.70 & 195.29 & 293.86 & 2.34 & 2.90 & 2.90 & 42.74 & 2.00 & 2.46 \\
\hline $25 \mathrm{P}$ & 88.32 & 122.92 & 203.80 & 300.03 & 2.54 & 2.99 & 2.91 & 38.70 & 1.81 & 2.12 \\
\hline $30 \mathrm{P}$ & 86.36 & 123.64 & 203.25 & 310.87 & 2.76 & 3.06 & 3.05 & 37.66 & 1.66 & 2.08 \\
\hline $35 \mathrm{P}$ & 88.61 & 122.80 & 205.94 & 312.20 & 2.50 & 3.01 & 3.00 & 34.89 & 1.56 & 1.83 \\
\hline $40 \mathrm{P}$ & 90.25 & 126.40 & 208.53 & 320.32 & 2.60 & 3.00 & 3.02 & 32.53 & 1.44 & 1.76 \\
\hline $45 \mathrm{P}$ & 88.64 & 120.27 & 197.80 & 291.18 & 2.35 & 2.87 & 2.83 & 28.44 & 1.37 & 1.66 \\
\hline $50 \mathrm{P}$ & 88.36 & 120.66 & 201.11 & 306.55 & 2.39 & 2.94 & 2.96 & 29.55 & 1.35 & 1.50 \\
\hline $55 \mathrm{P}$ & 91.57 & 120.73 & 198.78 & 306.74 & 2.13 & 2.77 & 2.88 & 24.80 & 1.16 & 1.52 \\
\hline $\begin{array}{l}\text { Pooled } \\
\text { SEM }\end{array}$ & 2.532 & 3.512 & 5.647 & 10.08 & 0.152 & 0.094 & 0.075 & 0.764 & 0.053 & 0.059 \\
\hline \multirow{2}{*}{$\mathrm{P}$ values } & Linear & 0.768 & 0.844 & 0.471 & 0.109 & 0.170 & 0.666 & $<0.001$ & $<0.001$ & $<0.001$ \\
\hline & Quadratic & 0.136 & 0.104 & 0.277 & 0.025 & 0.060 & 0.213 & 0.114 & 0.017 & $<0.001$ \\
\hline
\end{tabular}

$\overline{I W}$; initial weight, $W$; weight, $S G R$; specific growth rate, $M B W$, metabolic body weight, $F C R$; feed conversion rate, $P E R$; protein efficiency ratio, Pooled $S E M$, standard error of the means.

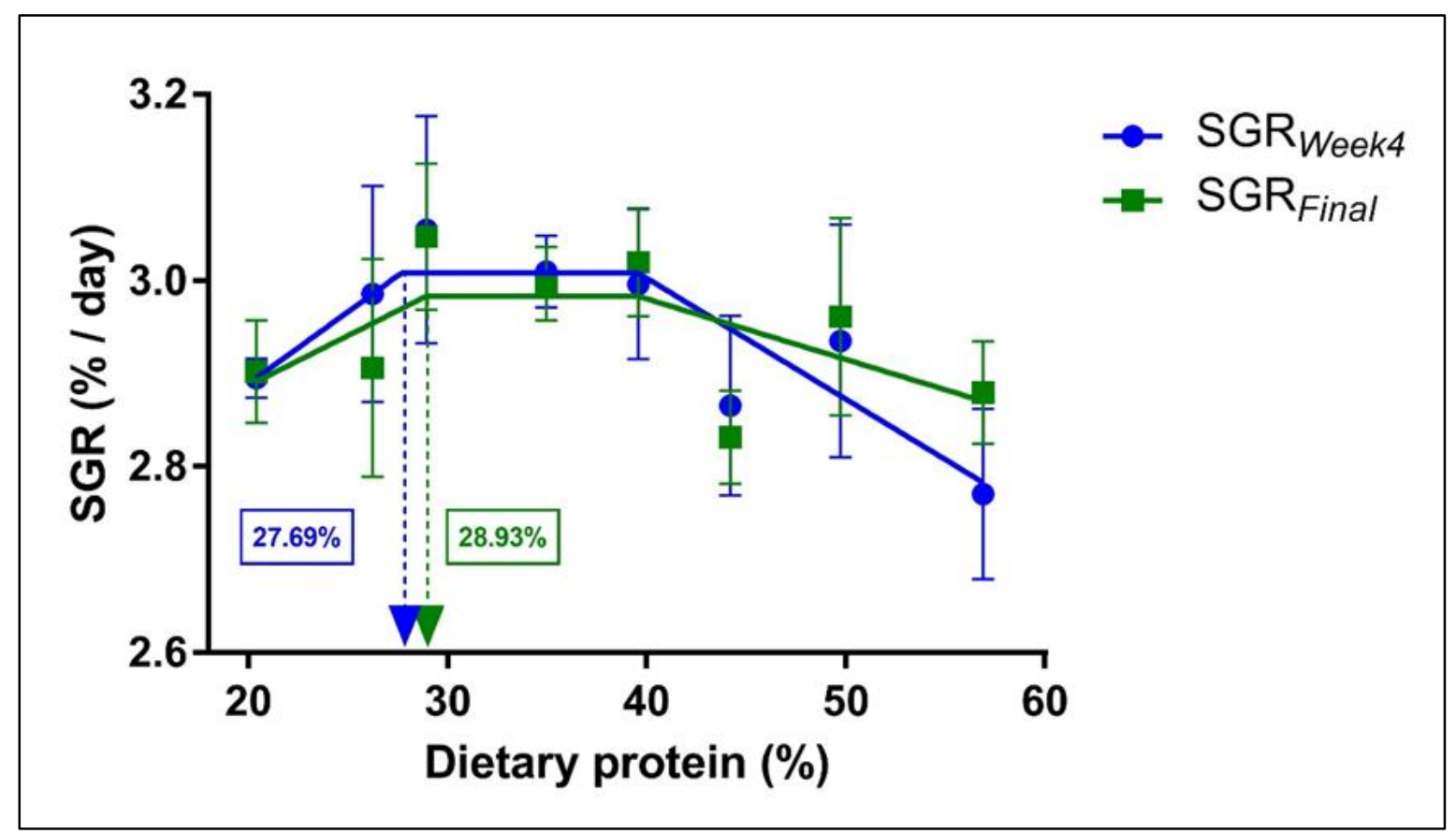

Figure 1. Effect of dietary protein levels on $S G R_{W e e k 4}$ and $S G R_{\text {Final }}$ values in zebrafish. Values are represented as the mean $S E M$ of three replicates. $S G R$; specific growth rate.

The whole body dry matter, ash and lipid concentrations linearly decreased with dietary protein levels $(\mathrm{P}=<0.001)$ whereas whole body protein was quadratically affected $(\mathrm{P}=0.050)$ (Table 3).

Daily protein and energy intakes by zebrafish quadratically decreased in response to dietary protein (linear, $\mathrm{P}=<0.001$; quadratic, $\mathrm{P}=<0.010$ ) (Table 4). On the other hand, no effect of dietary protein levels was observed on daily protein gain. Dietary protein levels linearly decreased daily energy gain and energy retention of zebrafish (linear, $\mathrm{P}=<0.001$ ), whereas quadratically decreased protein retention (linear and quadratic, $\mathrm{P}=<0.001$ ). 
Table 3. Whole body compositions of zebrafish fed varying levels of dietary protein (\%)

\begin{tabular}{|c|c|c|c|c|}
\hline Diets & Whole body dry matter & Whole body ash & Whole body lipid & Whole body protein \\
\hline Initial & 27.01 & 2.79 & 7.49 & 14.49 \\
\hline $20 \mathrm{P}$ & 30.95 & 3.09 & 9.82 & 16.14 \\
\hline $25 \mathrm{P}$ & 30.43 & 3.03 & 9.08 & 16.38 \\
\hline $30 \mathrm{P}$ & 29.96 & 3.09 & 8.55 & 16.14 \\
\hline $35 \mathrm{P}$ & 29.69 & 2.73 & 8.31 & 15.77 \\
\hline $40 \mathrm{P}$ & 30.09 & 2.92 & 8.24 & 16.37 \\
\hline $45 \mathrm{P}$ & 28.77 & 2.69 & 7.09 & 15.77 \\
\hline $50 \mathrm{P}$ & 28.55 & 2.62 & 7.07 & 16.17 \\
\hline $55 \mathrm{P}$ & 28.95 & 2.78 & 7.11 & 16.86 \\
\hline Pooled SEM & 0.351 & 0.084 & 0.296 & 0.302 \\
\hline Linear & $<0.001$ & $<0.001$ & $<0.001$ & 0.433 \\
\hline Quadratic & 0.227 & 0.117 & 0.049 & 0.05 \\
\hline
\end{tabular}

Pooled SEM; standard error of the means

Table 4. Nutrient utilization of zebrafish fed graded levels of dietary protein

\begin{tabular}{|c|c|c|c|c|c|c|c|}
\hline \multicolumn{2}{|l|}{ Diets } & $\begin{array}{c}\text { Daily protein intake } \\
\text { (g/kg } M B W^{0.8} / \text { day) }\end{array}$ & $\begin{array}{l}\text { Daily energy intake } \\
\left(k J / \mathrm{kg} M B W^{0.8} / \text { day }\right)\end{array}$ & $\begin{array}{l}\text { Daily protein gain } \\
\text { (g/kg } M B W^{0.8} / \text { day) }\end{array}$ & $\begin{array}{l}\text { Daily energy gain } \\
\left(k J / \mathrm{kg} M B W^{0.8} / \text { day }\right)\end{array}$ & $\begin{array}{c}\text { Protein } \\
\text { retention } \\
(\%)\end{array}$ & $\begin{array}{c}\text { Energy } \\
\text { retention } \\
(\%)\end{array}$ \\
\hline \multicolumn{2}{|l|}{$20 \mathrm{P}$} & 8.71 & 926.89 & 3.60 & 176.29 & 41.42 & 19.06 \\
\hline \multicolumn{2}{|l|}{$25 \mathrm{P}$} & 10.15 & 830.39 & 3.70 & 170.57 & 36.45 & 20.54 \\
\hline \multicolumn{2}{|l|}{$30 \mathrm{P}$} & 10.89 & 809.35 & 3.81 & 170.57 & 34.96 & 21.09 \\
\hline \multicolumn{2}{|l|}{$35 \mathrm{P}$} & 12.19 & 752.09 & 3.64 & 162.44 & 29.84 & 21.61 \\
\hline \multicolumn{2}{|l|}{$40 \mathrm{P}$} & 12.87 & 695.66 & 3.87 & 167.92 & 30.10 & 24.17 \\
\hline \multicolumn{2}{|l|}{$45 \mathrm{P}$} & 12.57 & 600.37 & 3.40 & 137.56 & 27.04 & 22.92 \\
\hline \multicolumn{2}{|l|}{$50 \mathrm{P}$} & 14.69 & 624.19 & 3.71 & 148.02 & 25.34 & 23.79 \\
\hline \multicolumn{2}{|l|}{$55 \mathrm{P}$} & 14.11 & 526.05 & 3.82 & 149.34 & 27.11 & 28.41 \\
\hline \multicolumn{2}{|c|}{ Pooled SEM } & 0.272 & 16.379 & 0.156 & 7.044 & 1.578 & 1.153 \\
\hline \multirow{2}{*}{$\begin{array}{l}\mathrm{P} \\
\text { values }\end{array}$} & Linear & $<0.001$ & $<0.001$ & 0.744 & $<0.001$ & $<0.001$ & $<0.001$ \\
\hline & Quadratic & 0.001 & 0.074 & 0.76 & 0.471 & $<0.001$ & 0.317 \\
\hline
\end{tabular}

Pooled SEM; standard error of the means, MBW; metabolic body weight

\section{Discussion}

The responses of zebrafish to dietary protein levels in the present study displayed some differences from those of the previous studies (Fernandes et al. 2016; O'Brine et al. 2015). This could be resulted from several factors including growth depensation in zebrafish, differences in strain and in number of sexes in experimental tanks and maturational stages as underlined previous authors (Biga and Goetz 2006; Eaton and Farley 1974). Since we did not define maturational situation and sexes of the individuals in the present study, we were unable to conclude their contributions to the differences in our results and those of O'Brine et al. (2015) and Fernandes et al. (2016).

$S G R$ s of zebrafish reared on increasing levels of dietary protein were affected as early as $2^{\text {nd }}$ week of the study with a significant quadratic trend, but with a lower rate during the later periods. This could be resulted from that the fish were not able to totally adapted to the experimental conditions even after a week of acclimation period. The SGR responses were abated but with still a significant quadratic trend at $4^{\text {th }}$ week, and became insignificant at the final, suggesting a decrease at the intensity of growth response with ages to dietary protein level. Although difficult to compare the results of this study with those of O'Brine et al. (2015) who used a higher range of dietary protein levels between 32 and $75 \%$, no significant treatment effect on growth rate of about 4month-old zebrafish was determined. The impacts of developmental stages on zebrafish growth rate has been previously underlined (Eaton and Farley 1974). Yet, we used $S G R_{W e e k}$ and $S G R_{\text {Final }}$ values as 
response variables to estimate the dietary protein requirements. The TBPLM estimated the requirements for $S G R_{\text {Week } 4}$ and $S G R_{\text {Final }}$ as 27.69 and $28.93 \%$ respectively without a considerable change with fish size. Dietary protein requirement levels of zebrafish estimated here are consistent with those of omnivorous species such as common carp and goldfish reported by NRC (2011) and Ulloa et al. (2011). But, our findings are lower than those levels of 37.6 and $44.8 \%$ for zebrafish by Fernandes et al. (2016), who used average estimated values of SKM and $B L M$ based on weight gain and protein retention. The model with two breaks used in the present study was previously employed by Klatt et al. (2016) for estimation of lower and upper critical dietary concentrations of methionine+cysteine for juvenile turbot (Psetta maxima). The second order polynomial model is widely used in estimation of nutrient requirements of aquaculture species (Shearer 2000), but the TBPLM fitted better in the present study in terms of residual sum of squares, suggesting that it can be used in future studies as an alternative model for determination of minimum nutrient requirements. When it comes to right side of the curve, the present model estimated an inhibition dietary protein level of $39.56 \%$. However, since the right side of the curve did not display a clear descending trend, a great caution should be exercised before a definite conclusion is reached in terms of inhibition level of dietary protein. The descending trend at the right side of $S G R$ s curve is inconsistent with previous observations in zebrafish (Fernandes et al. 2016; O'Brine et al. 2015), who found a plateau at high protein levels. We can conclude that our $S G R$ data appears to be suitable for estimation of only minimum dietary protein using the TBPLM model level but not for the inhibition level. Yet, care should be exercised that dietary protein levels above about $45 \%$ may lead to a reduction in growth performance of juvenile zebrafish, at least in the studied weight ranges.

Feed consumption of fish linearly decreased with the increase of dietary protein levels. This is consistent with the results reported by Akpinar et al. (2012) and Fernandes et al. (2016), who observed an inverse relation between feed intake and dietary protein in juvenile shi drum (Umbrina cirrosa) and zebrafish. This phenomenon could be attributed to compensatory response to get more protein in fish fed lower dietary protein levels, as argued by several authors (Akpinar et al. 2012; El- Dakar et al. 2011; Fernandes et al. 2016; O'Brine et al. 2015). Therefore, at restricted feeding regimes at the estimated requirement level in this study fish may not meet their daily protein requirements and significant attention should be paid to feeding levels in zebrafish laboratories. Our results related with $F C R$ showed a quadratic decrease in response to the increase in dietary protein, being consistent to a certain degree with those of Fernandes et al. (2016), who observed an improvement in feed efficiency up to $35 \%$ protein level, then a plateau.

A quadratic decrease in PER with increasing dietary protein level was the case in the present study. This suggests that zebrafish did not use increasing dietary protein particularly at above requirement levels for protein synthesis as indicated several fish species including Arctic charr, Salvelinus alpinus (Gurure et al. 1995), Zacco barbata (Shyong et al. 1998), marbled spinefoot rabbitfish, Siganus rivulatus (El- Dakar et al. 2011) and tiger puffer, Takifugu rubripes (Kim and Lee 2009).

The effect of dietary protein levels on whole body compositions of zebrafish was a significant linear decrease in dry matter, crude ash and lipid whereas no change in crude protein in the present study. Our dry matter results are consistent with those of Fernandes et al. (2016), but this was not the case in the whole body protein which displayed an increase with dietary protein levels in their study. Although no clear consensus about the effects of dietary protein levels on the proximate compositions of fish in the literature, Gurure et al. (1995) found a decrease in dry matter and crude lipid concentrations in Arctic charr with dietary protein levels, being fully in parallel with our findings. Higher lipid concentrations in zebrafish on lower dietary protein levels could be a result of higher depositions of energy due to higher feed consumption.

Expectedly, daily protein intake of zebrafish increased with dietary protein level. Similar results were also recorded by other authors in different fish species including zebrafish (Akpınar et al. 2012; ElDakar et al. 2011; Fernandes et al. 2016). However, this trend was not reflected to daily protein gain, which in turn resulted in a significant quadratic decrease in protein retention in response to increasing levels of protein as was the case in PER values. Although the protein retention data are in harmony with those by Fernandes et al. (2016) at a certain degree, daily protein gains are inconsistent with the findings of these authors. Our daily energy intake and gain values displayed a linear decrease with dietary protein levels but energy retention showed an inverse trend, being partly in parallel with the results of Fernandes et al. (2016).

In conclusion, the results of the present experiment show that zebrafish growing from 85 and $300 \mathrm{mg}$ require minimum 29\% dietary protein level in their diets including about $10 \%$ lipid or 19.5 $\mathrm{MJ} / \mathrm{kg}$ gross energy when fed ad libitum. Further studies are required to determine the effects of 
varying dietary protein to energy ratios at different feeding levels.

\section{Acknowledgements}

The authors would like to thank Fikri Çağlar Yücel, Hamza Toprak and Ramazan Dolaşık for their help during the experiment.

\section{References}

Akpınar Z, Sevgili H, Özgen T, Demir A, Emre Y. 2012. Dietary protein requirement of juvenile shi drum, Umbrina cirrosa (L.). Aquacult Res. 43:421-429. doi: $10.1111 / \mathrm{j} .1365-2109.2011 .02845 . x$

AOAC. 1990. Official Methods of Analysis, 15 ed., Association of Official Analytical Chemists, Arlington, VA, p.684

Biga PR, Goetz FW. 2006. Zebrafish and giant danio as models for muscle growth: determinate vs. indeterminate growth as determined by morphometric analysis. Am J Physiol Regul Integr Comp Physiol. 291:R1327-R1337. doi: 10.1152/ajpregu.00905.2005

Eaton RC, Farley RD. 1974. Growth and the reduction of depensation of zebrafish, Brachydanio rerio, reared in the laboratory. Copeia. 1974(1):204-209. doi: 10.2307/1443024

El- Dakar AY, Shalaby SM, Saoud IP. 2011. Dietary protein requirement of juvenile marbled spinefoot rabbitfish Siganus rivulatus. Aquacult Res. 42:10501055. doi: 10.1111/j.1365-2109.2010.02694.x

Fernandes H, Peres H, Carvalho AP. 2016. Dietary protein requirement during juvenile growth of Zebrafish (Danio rerio). Zebrafish. 13(6):548-555. doi: 10.1089/zeb.2016.1303

Gurure R, Moccia R, Atkinson J. 1995. Optimal protein requirements of young Arctic charr (Salvelinus alpinus) fed practical diets. Aquacult Nutr. 1:227-234. doi: 10.1111/j.1365-2095.1995.tb00048.x

Hernandez-Llamas A. 2009. Conventional and alternative dose-response models to estimate nutrient requirements of aquaculture species. Aquaculture. 292:207-213.

doi: 10.1016/j.aquaculture.2009.04.014

Kim S-S, Lee K-J. 2009. Dietary protein requirement of juvenile tiger puffer (Takifugu rubripes). Aquaculture. 287(1-2):219-222. doi: 10.1016/j.aquaculture.2008.10.021

Klatt SF, von Danwitz A, Hasler M, Susenbeth A. 2016. Determination of the lower and upper critical concentration of Methionine+ Cystine in diets of juvenile turbot (Psetta maxima). Aquaculture. 452:1223.

doi: 10.1016/j.aquaculture.2015.10.015

Lawrence C. 2007. The husbandry of zebrafish (Danio rerio): a review. Aquaculture. 269(1-4):1-20.

doi: 10.1016/j.aquaculture.2007.04.077

Markovich ML, Rizzuto NV, Brown PB. 2007. Diet affects spawning in zebrafish. Zebrafish. 4(1):69-74. doi: $10.1089 /$ zeb.2006.9993

NRC. 2011. Nutrient requirements of fish and shrimp. National Research Council of the National Academies, Washington DC.

O'Brine TM, Vrtělová J, Snellgrove DL, Davies SJ, Sloman KA. 2015. Growth, oxygen consumption, and behavioral responses of Danio rerio to variation in dietary protein and lipid levels. Zebrafish 12(4):296304.

doi: 10.1089/zeb.2014.1008

Robison BD, Drewa RE, Murdoch GK, Powell M, Rodnick KJ, Settles M, Stone D, Churchill A, Hill RA, Papasani MR, Lewis SS, Hardy RW. 2008. Sexual dimorphism in hepatic gene expression and the response to dietary carbohydrate manipulation in the zebrafish (Danio rerio). Comp Biochem Physiol Part D Genomics Proteomics. 3(2):141-154.

doi: 10.1016/j.cbd.2008.01.001

Shearer K. 2000. Experimental design, statistical analysis and modelling of dietary nutrient requirement studies for fish: a critical review. Aquacult Nutr. 6(2):91-102. doi: 10.1046/j.1365-2095.2000.00134.x

Shyong W-J, Huang C-H, Chen H-C. 1998. Effects of dietary protein concentration on growth and muscle composition of juvenile Zacco barbata. Aquaculture. 167:35-42. doi: 10.1016/S0044-8486(98)00313-5

Siccardi III AJ, Garris HW, Jones WT, Moseley DB, D'Abramo LR, Watts SA. 2009. Growth and survival of zebrafish (Danio rerio) fed different commercial and laboratory diets. Zebrafish. 6(3):275-280. doi: 10.1089/zeb.2008.0553

Smith Jr DL, Barry RJ, Powell ML, Nagy TR, D'Abramo L, Watts SA. 2013. Dietary protein source influence on body size and composition in growing zebrafish. Zebrafish. 10(3):439-446. doi: 10.1089/zeb.2012.0864

Ulloa PE, Iturra P, Neira R, Araneda C. 2011. Zebrafish as a model organism for nutrition and growth: towards comparative studies of nutritional genomics applied to aquacultured fishes. Rev Fish Biol Fisheries 21(4):649-666. doi: $10.1007 / \mathrm{s} 11160-011-9203-0$

Ulloa PE, Medrano JF, Feijoo CG. 2014. Zebrafish as animal model for aquaculture nutrition research. Front Genet. 5:313. doi: 10.3389/fgene.2014.00313

Yossa R, Sarker PK, Mock DM, Vandenberg GW. 2014. Dietary biotin requirement for growth of juvenile zebrafish Danio rerio (Hamilton-Buchanan). Aquacult Res. 45(11):1787-1797. doi: 10.1111/are.12124 